\title{
Can Obedience to Accounting Rules Moderate the Effect of Individual Morality, Internal Control and Fraud of Financial Statement?
}

\author{
Siti Noor Khikmah ${ }^{1}$, Dwi Rahayuningsih ${ }^{2}$ \\ \{noorkhikmah@ummgl.ac.id ${ }^{1}$ \} \\ Department of Economics and Business, Universitas Muhammadiyah Magelang, 56126, Indonesia ${ }^{1,2}$
}

\begin{abstract}
The purpose of this study was to examine the relationship between individual morality, internal control and fraud of financial statement with the obedience of accounting rules as a moderating variable. The sampling technique of this study was purposive sampling. This paper uses a Moderated Regrestion Analysis (MRA) method with total observation to 21 subdistrict and 5 village at Magelang district. The finding of this paper shows has not the association between internal control, individual morality and fraud of financial statement. Next, when this paper interact individual morality, internal control and fraud of financial statement is not moderated by obedience to accounting rules. The significant positive relationship between obedience to accounting rules and financial of financial statement. This findings show that obedience to accounting rules is an important role between internal control and fraud of financial statement. These findings are expected to inform regulatory bodies obedience on the role of obedience to accounting rules in financial reporting, which can assist in regulatory reforms and inform the Good Corporate Governance.
\end{abstract}

Keywords: Fraud of Financial Statement, Individual Morality, Internal Control, Obedience to Accounting Rules.

\section{Introduction}

Each business transaction is susceptible and have a risk of fraud. This condition indicates that none of companies invulnerable to fraud [1] and [2]. Post-reform, there has been a phenomenon in the development of the public sector in Indonesia is the strengthening of demands for accountability on public institutions, both at central and regional levels [3]. The existence of a decentralized system of state financial management down to the regional level has led to an increase in accounting fraud. In 2019, Indonesia was ranked 85th out of 180 countries, an increase of 2 points from 2018 (the Transparency International Institute Survey that Corruption Perception Index). The corruption case is most common misuse of funds of 154 cases with state losses of Rp 1.2 trillion, inflation (mark-up) as many as 77 cases and extortion as many as 71 cases. The agency recorded the highest number of corruptions is for districts with 222 cases and state losses of $\mathrm{Rp} 1.17$ trillion. This shows the corruption in the financial area is still quite high (IHPS, 2018). Cases of fraud occurring in government Magelang, involving Apparatus Civil State is the procurement of official cars by the staff of the Department of Revenue Financial Management and Wealth Asset (DPPKAD), corruption fines retribution by staff at the Department of Transportation, corruption by the head Disnakertransos against fines 
that the vehicle test and creating a fictitious memorandum warrant by the Chief Official Travel DPPKAD. The latest case by the State Civil Apparatus, the construction of a bridge of Rp 90.6 million (www.infokorupsi.com).

Research related to financial statement fraud has been widely studied, but from some of the results of research still found the gaps among others [4], between internal control, of individual morality effect on fraud, [4]-[10]. The difference in this study is to test the compliance of accounting rules as a moderating variable between internal control and morality of individuals to financial statement fraud. Their accounting rules to avoid actions that distorted and detrimental to the organization. Management's compliance with the applicable accounting rules in carrying out accounting activities is expected to reduce the unethical behavior. Accounting standards are arranged to form the basis of the financial statements. Accounting standards consist of guidelines that are used to measure and present the financial statements. Agencies that abide by all the guidelines in measuring and presenting financial statements in accordance with applicable accounting standards will reduce the opportunity gap and employee fraud. Regulation can deter someone from doing something that is not in accordance with the existing rules [11]. Organizational rules serve as a tool to ensure organizational goals are achieved [12].

The purpose of this study was to examine the relationship between internal control, individual morality and fraud of financial statement with the obedience of accounting rules as a moderating variable in the Magelang Regional Apparatus Organization. This study contributes to the implementation of internal control in the public sector. For paktisi can provide relevant evaluation of internal control implemented by local governments, and can as a basis for policy makers in the prevention of fraud in government agencies.

\section{Method}

The population of this study is the employee in Magelang Regional Apparatus Organization. The sampling technique of this study was purposive sampling, which is a sampling technique using certain criteria. The sample criteria used are (1) head of sub district or head of village, (2) secretary, (3) sub division head, (4) treasurer or financial employee. The sample of this research were 71 usable to the analysis. Data analysis techniques were using descriptive statistics and Moderated Regression Analysis (MRA) [13]. The research model shows as follows number 1 :

$\mathrm{FSF}=\mathrm{a}+\mathrm{b}_{1} \mathrm{IM}+\mathrm{b}_{2} \mathrm{IC}+\mathrm{b}_{3} \mathrm{OAR}+\mathrm{b}_{4} \mathrm{IM} \mathrm{M}^{*} \mathrm{OAR}+\mathrm{b}_{5} \mathrm{IC} * \mathrm{OAR}+\mathrm{e}$

Notes :

FSF : Financial Statement Fraud

IM : Individual Morality

IC : Internal Control

OAR : Obedience to Accounting Rules

\section{Results and Discussion}

\subsection{Result}

The result of descriptive statistic analysis showed in the Table 1. 
Table 1. Descriptive Statistic

\begin{tabular}{ccccc}
\hline Variable & Mean & Standar deviasi & Min & Max \\
\hline IM & 3.592 & 0.495 & 3 & 4 \\
IC & 3.507 & 0.504 & 3 & 4 \\
OAR & 3.549 & 0.501 & 3 & 4 \\
FSF & 3.493 & 0.504 & 3 & 4 \\
\hline
\end{tabular}

Source: Primary Data, 2018

Table 1 presents descriptive data for the sample. The average from 71 responden to answer statements about internal control, individual morality, obedience to accounting rules and fraud of financial statement are netral. Table 2 presents the summarized results for our Moderation Regression Analyses (MRA).

Table 2. Moderation Regression Analysis

\begin{tabular}{ccccc}
\hline Variable & $\begin{array}{c}\text { Estimated } \\
\text { Coefficients }\end{array}$ & Standar error & $t$-statistic & p-value \\
\hline Intercept & 0,324 & 0,331 & 0,979 & 0,331 \\
IM & 0,072 & 0,136 & 0,531 & 0,597 \\
IC & 0,094 & 0,128 & 0,738 & 0,463 \\
OAR & 0,544 & 0,131 & 4,139 & 0,000 \\
IM*OAR & 0,005 & 0,043 & 0,12 & 0,905 \\
IC*OAR & 0,049 & 0,044 & 1,115 & 0,269 \\
\hline
\end{tabular}

Source: Primary Data, 2018

The results of the regressions used to test our hypothesis. Based on the moderation regression analysis results presented in tables 2, we reject $\mathrm{H} 1, \mathrm{H} 2, \mathrm{H} 3$ that individual morality, internal control and obedience to accounting rules are not negatively associated with financial statement fraud. The result $\mathrm{H} 3$ is obedience to accounting rules is positevely associated with fraud of financial statement. We also reject $\mathrm{H} 4$ and $\mathrm{H} 5$ that the obedience to accounting rules has not been found to be moderated beetwen individual morality and internal control with fraud of financial statement.

\subsection{Discussion}

We have examined the effect of individual morality, internal control, obedience to accounting rules with fraud of financial statement. The results of one hypothesis test is individual morality has not effect on fraud of financial statements. Individual codes of ethics must be made in the organization, and will be a moral compass [14] for all employees who must be express issues and ethical integrity. Someone doing accounting fraud as the biggest cause is individual morality. Fraud is behavior that is unacceptable morally [15].

The result show that the internal controls is not negatively associated with fraud of financial statements. The internal control has not affected on fraud of financial statements in sub-districts and villages in Magelang Regency. This finding implies that internal control in the organization will not affect the chances of fraud in Sub-District offices in Magelang. There is internal control and monitoring of operational activities does not cause fraud. Internal control will be effective and efficient in the organization if all members of the organization are obedient. The based-on fraud triangle theory, the system will direct the organization to achieve the goals. The internal control will function well if there is commitment from all members of the organization [14]. 
The based-on description statistic that the internal control system in the public sector is not well implemented, can be seen from average answers of respondents netral with the statement items presented.

Fraud in form of corruption does not diminish or recede, but continues to develop systemically, propagating in all sectors and developing the structural system, the existence of a system formed, purposefully or not, tends to encourage people to commit corruption. This condition is caused the legislation has not been sufficient for efforts to eradicate corruption and the synergy and unity of action between law enforcers is still weak and harbors the problem of mistrust. A different and unbalanced system of incentives for officials in the public sector can increase corruption. These findings do not support the theory that internal control can prevent fraud of financial statements [16], and is inconsistent with studies [17], [18] that internal control can reduce fraud and significantly prevent fraud [19].

We also found a positive relationship between the obedience to accounting rules and fraud of financial statement. The obedience to accounting rules can increase fraud. Based of descriptif statistic is average answers of respondents netral with the statement items presented. The existence of financial rules that requires the financial accountability report to be zero or exhausted, it can cause fraud.

The results of the hypothesis test that obedience to accounting rules does not strengthen or weaken the relationship between individual morality, internal control and fraud of financial statements. There are differences tendency of accounting fraud between the individual with low morality and individual with high morality [6]. Someone commits accounting fraud depending on low or high individual morality [6]. Low individual morality has a tendency to commit fraud of financial statements than individual morality high. Kohlberg theory about morality indicates that individual with high morality (post-conventional) has an orientation on ethical principles.

The obedience to accounting rules is not strengthens the relationship between internal control and fraud of financial reporting. Based on the triangle fraud theory, internal control will affect the amount of opportunity to commit financial statements fraud. Weak internal controls can be used as an opportunity to commit fraud. Effective internal controls can protect against theft, embezzlement, misappropriation of assets which are supported by the obedience to accounting rules.

\section{Conclusion}

This research is conducted to ensure an empirical relationship between the activity of internal control and individual morality with fraud of financial statement at Regional Government Organization of Magelang District. This research is supported by fraud triangle theory which fraud of financial statement is caused by three aspects. Those are pressure, opportunity, and rationalization. A good internal control can function as base to decrease fraud of financial statement. Furthermore, it is also supported by literature review. The result showed that obedience to accounting rules can not moderate the relationship between individual morality, internal control and fraud of financial statement but the obedience to accounting rules become independent variable to fraud of financial statements. This research identified several points that are interesting and also created many new questions that need to be answered by further research. The internal control, individual morality and obedience to accounting rules are important in reduce fraud of financial statement in all Regional Government Organization, so this research need further investigation by expanding sample scope which is chosen and 
obtained more direct evidences that are influenced the fraud (for example, information asymmetry, compansation suitability, or unethical behavior).

\section{Acknowledgement}

The authors would like to thank the Ministry of Education and Culture of the Republic of Indonesia for their research assistance through the Domestic Postgraduate Education Scholarship which enabled us to conduct this research. Researchers are also grateful to the technicians who have helped collect data as well as reviewers

\section{References}

[1] P. Taylor, J. G. Murray, and J. G. Murray, "Procurement Fraud Vulnerability : A Case Study," ADPACS, no. December, pp. 37-41, 2014.

[2] M. Krambia-Kapardis and A. Zopiatis, "Investigating incidents of fraud in small economies: the case for Cyprus,” J. Financ. Crime, vol. 17, no. 2, pp. 195-209, 2010.

[3] Mardiasmo, Akuntansi Sektor Publik. Yogyakarta: Andi Offset, 2018.

[4] K. M. Zakaria, A. Nawawi, and A. S. A. P. Salin, "Internal controls and fraud - empirical evidence from oil and gas company," J. Financ. Crime, vol. 23, no. 4, pp. 1154-1168, 2016.

[5] G. A. K. R. S. Dewi, "Pengendalian Internal pada Kecurangan Akuntansi ( Studi Eksperimen pada Pemerintah Daerah Provinsi Bali ).," J. Ilm. Akuntansi, vol. 1, no. 1, pp. 77-92, 2016.

[6] S. Santy, "The Effect Of Internal Control And Individual Morality," Asia Pasific Fraud J., vol. 3, no. 1 , pp. 33-41, 2018.

[7] O. N. Joseph, O. Albert, and P. J. Byaruhanga, "Effect of Internal Control on Fraud Detection and Prevention in District Treasuries of Kakamega County,” Int. J. Bus. Manag. Invent., vol. 4, no. 1, pp. 47-57, 2015.

[8] M.-Z. Sanusi, N. Mohamed, and N. Omar, "Effects of Internal Controls , Fraud Motives and Experience in Assessing Likelihood of Fraud Risk,” J. Econ. Bus. Manag., vol. 3, no. 2, 2015.

[9] Wilopo, "Analisis Faktor-Faktor yang Berpengaruh Terhadap Kecenderungan Kecurangan Akuntansi : Studi pada Perusahaan Publik dan Badan Usaha Milik Negara (BUMN) di Indonesia," J. Ris. Akunt. Indones., vol. 9, pp. 21-37, 2006.

[10] V. Adelin, "Pengaruh Pengendalian Internal, Ketaatan Aturan Akuntansi dan Perilaku Tidak Etis Terhadap Kencenderungan Kecurangan Akuntansi," J. Akunt., vol. 1, no. 3, 2013.

[11] J. J. Maroney, "The Effects of Moral Reasoning on Financial Reporting Decisions in a Post SarbanesOxley Environment," Behavioral, vol. 20, no. 2, pp. 89-110, 2008.

[12] A. Lovell, "Some thoughts on Kohlberg â€TM s hierarchy of moral reasoning and its relevance for accounting theories of control," Account. Educ. An Int. J., vol. 6, no. 2, pp. 147-162, 1997.

[13] I. Ghozali, Aplikasi Analisis Multivariat dengan Program IBM SPSS 25'. 2018.

[14] J. T. Biegelman, M. T. and Bartow, Executive Roadmap to Fraud Prevention and Internal Control: Creating a Culture of Compliance. 1st ed. USA: John Wiley \& Sons, Inc., 2006.

[15] A. W. Tunggal, Pengantar Fraud Auditing. Jakarta: Harvarindo, 2008.

[16] W. C. Boynton and R. N. Johnson, Modern Auditing: Assurance Services and the Integrity of Financial Reporting, 8th ed. USA. Richard D. Irwin Inc, 2008.

[17] E. Yulina, "Pengaruh Moralitas Individu dan Pengendalian Internal terhadap Kecenderungan Kecurangan Akuntansi (Yulina Eliza),” J. Akunt., vol. 4, no. 1, pp. 86-100, 2015.

[18] E. . Onyuka and H. . Otinga, "Influence of Internal Control and Staff Compensation on Fraud Occurrence in Commercial Banks Branches in Kisumu County, Kenya," Strateg. J. Bus. Chang. Manag., vol. 6, no. 1, pp. 286-304, 2019. 
[19] A. O. Ayorinde, A. Toyin, and A. Leye, "Evaluating Internal Control System as Preventive Measure of Fraud in the Nigerian Banking Sector," Int. J. Manag. Sci. Bus. Res., vol. 2, no. 9, pp. 15-22, 2013. 